\title{
El Instituto Lingüístico de Verano y el Protestantismo En México
}

\author{
Margarita Santoyo R. y José Arellano S. \\ Facultad de Ciencias Politicas y Sociales UNAM
}

\section{Antecedentes, Origen y Fundación}

El Instituto Lingüístico de Verano (ILV) o Summer Institute Linguistic (por su nombre en inglés) es un organismo internacional con sede en Santa Ana, California. Lo componen aproximadamente 3500 lingüistas de diferentes nacionalidades, la mayoría son norteamericanos. Un primer sector cuyos orígenes se remontan a los años 1920-1930 fue iniciado por individuos sostenidos con fondos levantados en los Estados Unidos entre las Iglesias protestantes conservadoras o empresarios y fue dirigido al medio indígena en general; se trata de la Pioner Missionary Agency, del misionero Dale, quién estaba establecido en la localidad de Tamazunchale, en San Luis Potosí; y el Instituto Lingüístico de Verano/Wycliffe Bible Translator creado por William Cameron Townsend. Se autodenominaron misiones de fe. A partir de los años 1950 surgen otros grupos que podemos llamar transnacionales religiosas con metas no eclesiásticas sino más bien ideológicas. "Estas organizaciones transnacionales que responden a una política fomentada por el Departamento de Estado Norteamericano, financiado en buena parte por la Agencia Internacional de Desarrollo (AID). Estas libres empresas religiosas representan una baja proporción de los protestantes en México pero han llamado particularmente la atención tanto por su militancia como por el apoyo económico que han recibido de los sectores más conservadores de los Estados Unidos" (Bastian,1983:12).

\section{Estructura y Organización Interna}

El Instituto Lingüístico de Verano, se creó a la par de la Wycliffe Bible Translator (WBT), sin embargo una vez establecido se fusionaron quedando sólo como una organización, pero con funciones específicas. Así el Instituto Lingüístico de Verano queda como parte de la Organización Wycliffe Bible Translator 
(traductores Wycliffe de la Biblia); secta religiosa de cristianos protestantes que profesa la creencia en la redención a través de la muerte de Cristo, la divina inspiración y la autoridad de todas las escrituras canónica- protestantes, dedicadas a traducir la Biblia a todos los idiomas del mundo. Previendo la necesidad de contar con el respaldo económico de un organismo que propiciara el trabajo de los nuevos investigadores dentro del programa básico de difusión del texto de la Biblia, el Instituto Lingüístico de Verano, se respaldo en la Wycliffe Bible Translator. Desde esa fecha el Instituto Lingüístico de Verano se encargó de preparar las posibilidades de entendimiento del mensaje bíblico en la comunidad indígena y la Wycliffe Bible Translator de distribuir los textos y de financiar los programas. ${ }^{1}$ Los orígenes deístico de Verano y de la Wyckliffe Bible Translator son simultáneos y están ligados en los propósitos de expansión religiosa de sectas protestantes de los Estados Unidos. Posteriormente esta labor de proselitismo evangélico se vendría a enriquecer con la colaboración de otras instituciones, como la Sociedad Bíblica Americana. 461OEl ILV celebra contratos o convenios con los gobiernos y en coordinación con la universidad de Oklahoma organiza a los grupos y a su vez prepara y entrena a sus miembros “... el ILV está concebido como la organización responsable de los aspectos técnicos referentes a educación, lingüística y antropología social aplicada, mientras que la WBT es la organización encargada del financiamiento de los programas, la distribución de los textos religiosos, y el reclutamiento de misioneros, para el trabajo de campo" (Mariategui, 1979:6).

Desde su fundación en los en Estados Unidos en 1935, William Cameron Townsend logró, extenderlo por todo el mundo. Actualmente abarca 28 países y 531 grupos indígenas de Estados Unidos, Asia, África, América Latina y algunos de Europa. En este mismo año inició sus actividades en México, acompañado de sus estudiantes, previa autorización gubernamental, el Summer Institute of Linguistics, que tenía como objetivos inmediatos el estudio de los idiomas; aborígenes, con la preparación de vocabularios gramáticas, textos bilingües, etcétera. El protestantismo empezó a penetrar de manera sistemática entre los varios pueblos indígenas a partir de los años 1920-1940. ${ }^{2}$

1 Para la historia de este organismo consultar a Wallis Bennett, 1959. Cfr. la bibliografía de Townsend

2 Para 1936, trabajaban con lo nahuas, otomí, hucholes, tarahumaras, mayas, tarascos, mazatecos, mixes, mixtecos, totonacas, entre otros. 


\section{Formas de Reclutamiento de los Misioneros}

Los miembros de la organización firman juramento de lealtad cada seis años, se instruyen en lingüística, y sobrevivencia (en la selva o en el ártico), dependiendo a donde vayan a ser enviados a trabajar. Trabajan en equipos de dos personas que pueden ser matrimonios o personas solas bien capacitadas. "En los lugares en donde se instalan, construyen una vivienda y la infraestructura necesaria de comunicación y transporte con un base central regional. Por medio de informantes asalariados, generalmente jóvenes comienzan a introducirse en el lenguaje y la cultura del grupo. Los equipos misioneros mantienen un contacto estrecho con su base de operaciones que cuentan con laboratorio de lenguas servicios médicos, bibliotecas, estación de radio, escuela para los hijos de los misioneros, etcétera. (JAARS)" (Mariategui, 1979:8).

Por otra parte, los misioneros lingüistas del ILV, protestantes o pertenecientes a sectas de origen Norteamericano, son personas de escasos recursos económicos y de un nivel cultural mediano... provienen de una población apolítica pero sujeta, en su educación y en su posición social, a las motivaciones religiosas conservadoras y anticomunistas. Firmes creyentes de la forma de vida norteamericana (American Way of Life) como idónea para todos los pueblos del mundo y de la religión protestante como única salvación posible. ${ }^{3}$ Los misioneros llegaron con la conciencia de pertenecer a un pueblo elegido por Dios. “... el misionero norteamericano en México sentía la necesidad de transmitir esta experiencia del 'destino manifiesto'. En este sentido, tenía la confianza de que el Dios que les había evangelizado primero y luego dinamizado, multiplicado y bendecido sobre todos los demás pueblos, armándoles con acero, valor y rayos, y enviándoles a ser la vanguardia de la humanidad otorgaría también una oportunidad nueva a los hermanos latinos" (Thomas Wood citado por Bastian, 1983:83)

3 Cfr. Gilberto Giménez La identidad social o el retorno del sujeto en sociología. También a J.P. Bastian. Breve historia del protestantismo, ya H.R. Niebuhr. The social sources of denominationalesm, donde se considera al norteamericano como un campo típicamente denominacional, con la aplicación del modelo mercantil de economía libre del fenómeno religioso obliga a las denominaciones a una creciente racionalización de sus actividades, por lo cual se vuelve inviable y costosa, que a la larga se convertirán en trust. Considerando que este tipo de denominaciones no detentan el monopolio de los bienes simbólicos de salvación y no se plantea una relación privilegiada con el Estado Esto es válido para Estados Unidos no para América Latina y menos para México, donde muchas sectas establecidas se otorgan el status ideológico de denominación. 


\section{Características Religiosas e Ideológicas}

\section{a) Misioneras Protestantes}

La orientación religiosa por la que se guían es la fundamentalista, misma que sostiene que la salvación se logra por medio de la lectura y estudio de los evangelios del Nuevo Testamento. Esta teología lleva una orientación ideológica: mediante el mensaje salvacionista, trata de imponer un modelo de dominación cultural que acreciente el individualismo, el apoliticismo, el conformismo y una actitud pasiva ante los problemas sociales. El papel que deben cumplir los miembros es propagar el evangelio “...me dijo que era de Estados Unidos y entonces dice, ante todo nuestra primera motivación es glorificar a Dios y construir su Iglesia entregando las escrituras a cada hombre en su propia lengua.. ${ }^{4}$ Lo que se persigue es la conversión religiosa, y así, el estudio lingüístico no es más que un aspecto secundario, una estratagema. "La conversión religiosa del indígena lleva consigo el rechazo a sus creencias" y formas de organización, la religión como ideología, refleja las condiciones de la vida material que la produce, de manera que al imponerse conlleva, en mayor o en menor grado, la aceptación de ciertas relaciones de producción, de ciertas formas sociales (...) la cuestión religiosa esta puesta al servicio del imperialismo y de su política neocolonialista" (Pike, 1974). La misión que no podían emprender los protestantes, la realiza el ILV. La enseñanza "bíblica que 'imparten' a partir de la formación de maestros bilingües, "consiste" tanto en realizar estudios de lenguas como capacitar a maestros para servir de elementos de desestructuración de los grupos nativos" (Dávila, 1975).

\section{Educativas. Bilingüismo-Bicultural}

Los misioneros lingüistas cubren muchos grupos étnicos, ellos cuando van a estudiar un idioma lo buscan lo más "puro" posible, en las comunidades donde hablen muy poco español, con el supuesto de la alfabetización por medio del método indirecto de castellanización sobre el cual investigadores mexicanos han demostrado su falacia. Por otro lado, los misioneros lingüistas han logrado, por parte de los gobiernos mexicanos, concesiones que les han permi-

4 Información directa proporcionada por Lucio Cardoso en Arroyo Tomate, Lalana, Oax 1989.

5 La costumbre de nosotros, quiero que sepan, eso si lo vamos a ver, nosotros tenemos otras costumbres. Información recabada en campo, proporcionada por el que fuera informante clave de Calvin Rench. Arroyo Tomate, Lalana, Oax. 1989 
tido una entera libertad de adoctrinamiento religiosos, de desvirtualización de los patrones culturales autóctono $s$, de conducción al apoliticismo y además a desvirtuar la cultura nacional.

Según Ricardo Pozas, "La manipulación en los programas indigenistas ha presentado diferentes tendencias: se ha manipulado a los indios para hacerles creer que lo que les conviene es su educación, y que es ésta la que dará solución a sus problemas. Se les manipula para imponerles un programa de enseñanza en su propia lengua que favorezca la penetración cultural de los norteamericano y las sectas religiosas que quieren salvar su alma, se manipula para impedir que el indio tome decisiones políticas efectivas en beneficio de la comunidad, pues la toma de decisiones políticas, son potestad de los caciques y de los funcionarios oficiales, la democratización no se permite y si se presenta, se manipula para evitar que funcione evitando las asambleas y reuniones"(Pozas, 1976:32).

\section{Expansión y Entrada en Países Pobres con Existencia de Minorías}

Los grupos étnicos afectados por el ILV son múltiples, sobre todo si consideramos que en México existe un mosaico étnico, es decir, México desde este punto de vista no es un país homogéneo sino multiétnico. El estado de Oaxaca reviste una gran importancia, si consideramos que de los tres millones de habitantes existentes en el estado, un millón novecientos mil son indígenas con insatisfacción de necesidades básicas haciéndola más vulnerable. Por otra parte, la entrada del IL V en áreas muy apartadas e inaccesibles se realiza debido en primer lugar a la poderosa infraestructura de movilización que posee; en los años 40 llegan los primeros miembros del ILV (Pike, 1974) con el aval del gobierno mexicano y con el apoyo de antropólogos indigenistas se internan en los lugares más recónditos de la sierra, donde jamás había llegado vehículo alguno; y en segundo lugar, buscando las comunidades étnicas de diferentes minorías mas preservadas en su aislamiento con sus relaciones hacia la sociedad nacional, aparentemente en la búsqueda de una "pureza" del lenguaje. Con un $90 \%$ de monolingües en la población, se justifica la elección de una comunidad.

El ILV es un organismo en expansión que tiende a cubrir los grupos minoritarios existentes, destacando el continente latinoamericano, sirviendo a los aparatos del Estado, compañías transnacionales y a los intereses económicos locales, "tratándose de etnias a las que la historia ha colocado en relaciones de interacción desigual, siempre resulta posible partir de un balance cultural elaborado bajo la hipótesis de su autonomía previa, para describir e interpretar posteriormente, por referencia a ese estado primero' de inocencia' 
simbólica, los cambios de sentido y de equilibrio, las contribuciones o las amputaciones, las alteraciones o las reinterpretaciones que produce la instauración de la relación desigual" (Passeron,1987:4). Si bien es cierto, el ILV ya no se encuentra operando de manera oficial ${ }^{6}$ en las comunidades chinantecas de Lalana, sin embargo, es a raíz de la permanencia de éste, como otros grupos protestantes han podido penetrar en las comunidades, muchos siguiendo los mismos mecanismos de acercamiento entre la gente. En cuanto a la dinámica de las sectas, éstas penetran en las comunidades indígenas por las necesidades que tienen éstas, así; en este sentido, se introducen con una disciplina mística ortodoxa, en donde se crean grupos que de manera pública hacen constar la no aceptación de otras ideas, ni conceptos una vez que se les han inculcado valores, e imágenes de carácter protestante.

En ese momento surge el divorcio con aquellos individuos que no comparten sus ideas.

\section{La Posición del Estado Mexicano}

En México a partir de los años 1930, el protestantismo empezó a penetrar de manera sistemática entre las diversas minorías étnicas del país. ${ }^{7}$ En ese

6 Expulsión del ILV en los países donde realiza actividades En Colombia, el general Matallana presentó un informe en 1974, sobre los 12 años de actividad del ILV, y declaraba que el gobierno colombiano había sido engañado por el Instituto, al presentarse bajo la apariencia de una institución científica dedicada a la lingüística, pero escondiendo otros intereses como el adoctrinamiento, no contemplado en el convenio. Sus actividades reales en Colombia habían sido: adoctrinamiento religioso; localización y explotación ilegal de recursos naturales; contrabando y tráfico de estupefacientes; exportación de flora y fauna hacia los Estados Unidos. Cfr Revista del Tercer Mundo. México №3. pp. 63. Curiosamente, existía un acuerdo firmado con las fuerzas armadas del Perú para trabajar en una zona indígena, colindante con Ayacucho, donde se encuentran los guerrilleros de Sendero Luminoso (Grupo guerrillero de filiación maoísta). Además, pretende colaborar con el Estado en los programas de colonización de la selva, con el fin de explotar los ricos y abundantes recursos naturales como fuente posible de solución a la crisis económica que sufre el país. El 25 de abril de 1976, ante la avalancha de ataques al ILV, un grupo de intelectuales firma un manifiesto en defensa del Instituto poniéndolo como "ejemplo científico sin parangón. Véase el Periódico Expreso Lima, Perú, 25 de abril, 1976. La NACLA (Congreso Norteamericano para América Latina), expone a la prensa internacional al ILV, registra los siguiente datos: en América Latina dicho Instituto controla más de 1000 misioneros lingüistas, que trabajan en aproximadamente 350 comunidades de indígenas

7 No es por casualidad que el protestantismo en la sociedad mexicana, presenta su mayor crecimiento justo en los anos correspondientes a la mayor expansión económica en el país (1950-1980). 
entonces, el gobierno del General Lázaro Cárdenas, su preocupación especial por las condiciones de vida de los indios y de los campesinos, se puede considerar que en esta época se da lo que se denomina "integración vs. asimilación vía castellanización, en este período el gobierno cardenista apoyó muy particularmente a uno de los grupos misioneros protestantes: El Instituto Lingüístico de Verano que por razones de estudio de las "lenguas indígenas", desde esos tiempos trabajan en nuestro país. ${ }^{8}$ Estaba reciente el movimiento cristero, por lo tanto la libertad de culto estaba garantizada, aunado a las creencias de sus colaboradores, Moisés Saénz y José Vasconcelos. México, en ese entonces, no contaba con una política indigenista, todavía faltarían 10 años para que se creara el Instituto Nacional Indigenista (INI) y 5 años para que se formara el Instituto Interamericano Indigenista (III), ${ }^{9}$ allí se fraguó la política integracionista, y el cual empezaría a determinar políticas indigenistas para América Latina y para México posteriormente, a través del INI.

Las comunidades se consideraron como un factor de retraso para la modernización del país. La política estatal en materia agraria era el reparto de tierra (populista) el impulso a la forma de propiedad ejidal. La fundamentación de la política indigenista de integración, requería de la alfabetización y castellanización de las minorías étnicas existentes, abrir nuevas fuentes de trabajo y recursos naturales al desarrollo capitalista del país. Sin embargo, el país carecía de los especialistas antropólogos y lingüistas y de las formas de producirlos y es con Cárdenas que se impulsa la formación de estos especialistas en México, bajo el proteccionismo académico de maestros, planes y programas, esencialmente norteamericano, ${ }^{10}$ maestros como Sol Tax; George P. Murdock; Franz Boaz; entre otros, formaron en ese entonces las primeras generaciones de antropólogos y lingüistas mexicanos. El aspecto de la colaboración docente se refiere a la participación de los especialistas del Instituto en cursos que deben realizarse para la preparación de personal mexicano. El Estado delega así, su política lingüística antropológica en instituciones pseudo científicas norteamericanas de carácter religioso fundamentalista.

$8 \mathrm{~J}$ unto, coincidiendo o con motivo de la presencia del ILV, aparecieron mud las otras sectas de origen norleamericano. Véase Clodomiro Siller Indigenismo y Protestantismo, en Cuadernos de Teología. No 10.

91940 en el Congreso Indigenista de Pátzcuaro.

10 El funcionalismo y el estructuralismo, empirismo descriptivo, las teorías folk, etc. 
El programa del instituto esta constituido por tres acciones específicas:

A) La esfera científica. Lingüístico. Idiomas no escritos

B) La esfera cultural, social y antropológica. Vivir entre un grupo autóctono

C) La esfera espiritual. Llevar el Nuevo Testamento.

Para lograr estas acciones era necesario un conocimiento irreprochable de las lenguas indígenas, por tanto consideraron, como uno de los significados del intercambio, que la inversión de recursos humanos tendría sus beneficios en los años futuros. "Este programa se planificaría en los ordenes... que permita la modesta participación de sus directores e investigadores..., pero básicamente en el estudio de la lingüística, de la antropología y del mensaje evangélico" (Ochoa, 1975 :45) ya que el idioma constituye un factor fundamental en la existencia y en el proceso de liberación de cada pueblo, ahora bIen, ha considerado que el hombre tiene dimensiones físicas intelectuales y espirituales y que por ello su programa debe completar estas tres importantes fases de la vida.

De esta manera los puntos fundamentales del programa son los siguientes:

"1. Estudio racional de los idiomas aborígenes;

2. Aplicación práctica de los resultados. Hábito de lectura;

3. Traducción de obras de alto valor moral, las sagradas escrituras. ${ }^{11} \mathrm{Pu}$ blicación de vocabularios bilingües en español e idiomas nativos, diccionarios, etcétera.

\section{Cooperación institucional;}

5. Proporcionar entrenamiento lingüistico a jóvenes;

6. Promover, que los indigenas, necesitan acceso a los valores representados por la invasión del mundo moderno a sus esferas culturales.

Los indigenas necesitan estar preparados y los valores fundados en la Biblia tienen una gran y positiva influencia para integrarlos correctamente" (Mendoza citado por Ochoa, 1975:48).

Dentro de la política de trabajo están claramente marcados los propósitos:

"1. La institución debe tener ante todo una misión: no se trata simplemente de cumplir determinadas tareas hay que mirar más alto y más lejos: hay que comprender al hombre y sentir el significado y la responsabilidad de una misión en bien del individuo, de la sociedad, de la nación;

2. El primer objetivo por alcanzar es llegar a la conciencia del hombre para ganarse su confianza;

11 Como instrumento para la solución de los problemas del vicio, la ignorancia y la superstición en la comunidad indígena. 


\section{Despertar la sensibilidad humana;}

4. Afirmar la noción de responsabilidad que emana de la fe en Dios, en la conciencia de los propósitos deberes y en el respeto que se debe a los demás" (Mendoza citado por Ochoa, 1975:48). Los programas de investigación sobre las minorias religiosas, étnicas y sociales, tiene como objetivo identificar dentro de estas formaciones sociales que puedan ser manejadas en ventaja de los interés estratégicos de E. $U$.

Como dice Enrique Maza, "El estado Mexicano ha prestado apoyo incondicional al ILV debido a la complementariedad de funciones que encuentra en este organismo para la consecución de su proyecto indigenista y la eficaz tarea político-ideológica encaminada a la domesticación de la población” (Maza, 1977:37).

El ILV, ahora como Asociación Civil, sigue operando en la región, aun cuando la Secretaria de Educación Pública dio por finiquitado el convenio suscrito, a principios de 1980, ${ }^{12}$ sus operaciones siguen normales, a tal grado que el servicio de avioneta sigue operando y sus oficinas en la ciudad de Mitla continúan abiertas e inalterables. El ILV sigue trabajando Igual que antes, sólo que ahora sin reconocimiento oficial. Para los lingüistas vale la pena tratar de hacerlo que quedarse con los brazos cruzados, vale la pena correr el riesgo.

\section{La Posición de la Iglesia Católica Ante el ILV y las Sectas Protestantes}

\section{La posición de la Iglesia Católica}

Las breves consideraciones sobre la religión demuestran que los indígenas han adoptado relativamente poco de la fe cristiana. La situación débil de la Iglesia Católica de hoy, que se hace notar visiblemente en el hecho de que en los municipios indígenas casi no hay sacerdotes permanentemente establecidos, existe desde hace aproximadamente 100 años. En los años anteriores tampoco llegó a tener cada comunidad su propio cura que viviera permanentemente entre ellos. Sin embargo, llegó a haber varios curas en el hinterland indígena de cada diócesis, quienes atendían una o varias comunidades. El éxodo de los sacerdotes se debe, por una parte, principalmente a la lucha que se desató contra la iglesia como consecuencia de la Reforma, a mediados del siglo pasado y, por otra, a la dispersión de las comunidades.

Durante la mayor parte del tiempo transcurrido desde entonces, el contacto de las instituciones de la Iglesia Católica se ha limitado a que un cura de

12 Véase Diario Oficial de la Federación. 
la diócesis haga una visita a la cabecera del municipio el día del Santo Patrón y quizá, algunas veces más a lo largo del año para celebrar misa y bautizar a los recién nacidos. Desde los principios de los años 50 aproximadamente, la situación ha cambiado en cuanto que algunos municipios reciben con mayor frecuencia la visita de un sacerdote; tal es el caso, por ejemplo, de las comunidades mas cercanas que reciben esta visita una o dos veces por mes, incluso cada semana. Se puede suponer que el incremento de la actividad de la Iglesia Católica tiene su raíz en el mejoramiento de las relaciones entre el Estado y la Iglesia, que se inició en la presidencia de Ávila Camacho (1940-46).

Junto a esta mayor libertad de acción de la iglesia, que se extiende a todo el país, debe tener importancia el hecho de que desde fines de los años $40 \mathrm{em}$ pezaron a actuar entre los indígenas misioneros protestantes. Tales actividades condujeron al hecho de que hasta el año de 1960 más de un tercio de los indígenas se convirtió al protestantismo. La Iglesia Protestante establecida firmemente en Arroyo Tomate pudo ejercer su influencia también en los municipios vecinos, aunque en menor medida. La actividad reforzada de la Iglesia Católica aún no ha conducido a un cambio considerable en la religión de los indígenas. El único sacramento aceptado sigue siendo el bautizo, pero éste lo ejerce incluso un chaman. Asimismo, los indígenas van pocas veces a misa o a confesarse. ${ }^{13}$ Tal postura cambia cuando, por ejemplo, se desata una epidemia. Entonces, las autoridades indígenas piden al cura que celebre una misa especial como complemento de sus actos rituales. En tiempos normales el papel del sacerdote se limita al de ser cura para los ladinos que viven en el lugar. La posición de la Iglesia Católica era más fuerte antes del éxodo de los sacerdotes, aunque la influencia de los curas en la religión de los indígenas parece haber sido muy limitada incluso en los siglos anteriores. Se puede suponer que esto se debe en gran parte a que el número de sacerdotes que trabajan entre los indígenas siempre fue demasiado bajo, y que por otra parte el afán misionero había disminuido bastante en el curso del siglo XVII. Tomando en cuenta tales sucesos no debe sorprender el hecho de que los indígenas jamás recibieran una imagen somera del cristianismo. Su poca comprensión de la enseñanza cristiana se desprende de múltiples quejas originadas por los curas. Informes de tal tipo existen en todos los siglos desde la conquista.

13 En San Andrés Larráinzar, Chiapas, lugar que es visitado por un cura semanalmente se puede observar claramente este fenómeno. 


\section{El proceso de evangelización}

El proceso de evangelización en esta región se inicia en 1548 por frailes dominicos desde el convento de Villa Alta y en 1559 por franciscanos en la jurisdicción de Teutila. ${ }^{14}$ Entre estos primeros frailes destaca fray Francisco de Sarabia, quien de 1581 hasta 1622 trabaja como misionero entre los chinantecos de la región de Choapan. Según los relatos de Burgoa, De Sarabia, reconociendo el valor de la lengua de los naturales en el proceso de evangelización, se convierte en el primer alfabetizador de los chinantecos. A él se deben los primeros textos escritos en este idioma. Otro de los frailes que también destaca por sus trabajos en chinanteco es fray Nicolás de la Barreda, cura de la parroquia de Yolox de 1708 a 1728. A él se debe la Doctrina cristiana en lengua chinanteca, publicada en 1730, uno de los documentos más importantes para el estudio de la lingüística histórica de la variante de Yolox.

El proceso de evangelización entre los chinantecos encontró su principal obstáculo y resistencia en el propio idioma de este grupo. En la mayoría de los casos los frailes no pudieron aprenderlo y la conquista espiritual de la región no fue una empresa fácil. Sin embargo, un número considerable de indígenas había sido bautizado, pero por lo general, no habían recibido ninguna instrucción o sólo una muy limitada, en la que a veces se había omitido la pasión de Jesucristo, lo cual obedecía al hecho de que los españoles se hacían pasar al principio por inmortales, y no querían representar a su Dios en el momento de su impotencia. La idea más firme tenían los indígenas del cristianismo, se refería a la Virgen María, ${ }^{15}$ y los españoles pudieron darse cuenta de que muy a menudo la evocaban. Los indígenas llamaban a la iglesia "Casa de la Santa María".

Por lo general, los indígenas veían dioses en las imágenes de los santos y suponían que tales imágenes tenían el mismo significado que sus propios ídolos. Las imágenes de los santos se clasificaban conforme a una especie de escala relativa a la eficiencia para conseguir una buena cosecha o para vencer otro tipo de problemas. En su intento por llevar la misión a los indígenas del hinterland, los dominicos a veces tropezaban con grandes dificultades, permitieron a los padres predicar con todo detalle el evangelio, pero cuando hubo terminado la instrucción, que duraba varios días, los indígenas rechazaban categóricamente la idea de dejarse bautizar.

14 En el año de 1545 cuando los misioneros dominicanos llegaron a la ciudad Real se percataron de este hecho

15 Se puede considerar que es a partir de entonces que en México se inicia el marianismo como una forma del cristianismo y de la evangelización. 
A fines del siglo XVII, aproximadamente 150 años después de haberse iniciado la misión, el obispo Núñez de la Vega relata lo concerniente a la fe indígena en un alter ego, la veneración de la Ceiba y la adivinación, con la ayuda del calendario tradicional indígena. Como consecuencia de la confrontación con un gran número de elementos no cristianos en la fe y la práctica religiosa de los indígenas, se vio obligado a escribir una carta pastoral en la que reprueba el "nahualismo primitivo" de aquéllos. En la esfera de tal concepto reúne los más diversos aspectos de la "superstición indígena”. De especial interés es la afirmación en la que se señala que los indígenas, incluso en el lecho de la muerte, no están dispuestos a confesar tales "horribles pecados". Tal postura de los indígenas posiblemente indica que no aceptaban los curas como autoridades en el terreno de su religión.

Las afirmaciones de Núñez de la Vega se complementan con las impresiones que relató un sacerdote en el año 1713. El cura se queja que los indígenas eran en su mayor parte estúpidos y malévolos, que tuvieran una gran afición a la superstición y la idolatría y de que se interesaran solamente en las ceremonias que se relacionaban con una gran algarabía y las danzas. Respecto de los santos mostraban una gran preferencia por los que estaban representados a caballo o junto a animales.

También es sumamente revelador el relato que en el año de 1781 redactó el obispo Francisco Polanco Carrera y Bustillos después de haber inspeccionado varias comunidades tzotziles que pertenecían al vicariado de Chamula. Se sorprendió mucho del hecho de que los chamulas que vivían en la vecindad de la Ciudad Real requirieran de un intérprete en su trato con los españoles. Su impresión general fue la de que los indígenas todavía se encontraban en el mismo estado que privaba unos 20 años después de la conquista. Le disgustaron las estatuas de los santos y quiso enterrarlas, pero tuvo que abandonar el intento porque estos santos vetustos les ayudaban mucho en sus problemas. De manera similar tuvo que abandonar el proyecto de sustituir la estatua del Santo Patrón en San Pedro (Chenalhó) por una nueva. El obispo se mostró especialmente sorprendido por la "osadía y la desvergüenza" que manifestaban los indígenas al mandar en la iglesia sin respeto al cura y al decir que la Tercera Persona de la Santa Trinidad era el Sol. Según opinión del obispo, tal situación era consecuencia de la escasa atención de las instituciones civiles y eclesiásticas respectivas.

La supervivencia de las ideas religiosas tradicionales indígenas, se mostró también con toda claridad durante las rebeliones de 1712-13 y 1869-79. Es posible que los elementos no cristianos se debilitaran en los siglos anteriores, cuando todavía se disponía de varios curas que vivían permanentemente 
en las comunidades indígenas, y se manifestaran principalmente en la vida religiosa de los parajes. El éxodo de curas que ocurrió hace aproximadamente 100 años -y que en realidad fue más bien una expulsión- y la consiguiente independencia de las autoridades religiosas indígenas, deben haber contribuido a que las ideas tradicionales ganaran nuevamente en importancia y a que el sincretismo que ya existía se consolidó aún más.

La Iglesia Católica ha dejado de ser en México la ocupante privilegiada y pacífica del campo religioso; éste se ha ido transformando progresivamente en un "campo de disputa" en virtud de la competencia creciente de innumerables sectas fundamentalistas que lo han infiltrado" (Giménez, 1989:6), de costa a costa y de frontera a frontera. Sin embargo, respecto a las culturas populares étnicas y regionales, la Iglesia Católica sigue siendo indiscutiblemente, la principal proveedora de símbolos, de normas y de modelos de comportamiento.

En este sentido, es importante conocer la reacción de la Iglesia Católica ante la proliferación y aceptación de otros credos. Para los miembros de la Iglesia Católica es mayor la preocupación por las causas que originan el cambio religioso de adeptos que la pérdida de los mismos. "Es la ignorancia lo que mueve a muchos a abandonar el catolicismo para incorporarse a otras corrientes religiosas de poca tradición en el país, es decir, las sectas". ${ }^{16}$

A raíz del Concilio Vaticano II se impuso el ecumenismo, es decir una posición de diálogo hacia las denominaciones cristianas no católicas. En este documento se da un reconocimiento de la libertad religiosa, no obstante, el espíritu del documento insta a no contentarse simplemente con condenar y combatir a las sectas o hacer que se prohíban o expulsen, o rescatar a los' adeptos' en contra de su voluntad. Los nuevos movimientos presentan como desafío religioso el estimular a la comunidad a la renovación para una mayor eficacia pastoral.

\section{La Iglesia Católica en la Chinantla y las Sectas Protestantes}

La gente se cambia porque está cansada de la misma estructura, la Iglesia Católica es vieja y tiene muchos años, quieren algo nuevo. El mundo de hoy tie-

16 Información proporcionada por los párrocos de la comunidad de El Arenal, San Juan Lalana, 1990. Otra de las causas, es la falta de fe y el cansancio, según declaraciones del obispo Muñoz Núñez. El porcentaje de miembros que han perdido la fe, baja del 97 al 94\% De acuerdo a las estadísticas de la iglesia se requiere en promedio un sacerdote por cada 4000 fieles, en la actualidad se tiene uno por cada siete. Si consideramos en poblaciones rurales, podemos ver el porque de la expansión de las sectas 
ne una necesidad desesperada de la palabra de Dios, y una Iglesia que no tiene ya más que decir sino aquello que el hombre puede aprender por sí mismo no tendrá pronto ya nada que decir a ese hombre. ${ }^{17}$ La gente se cambia en busca de algo nuevo, las sectas llegan ofreciendo ese cambio, hay un gran sensacionalismo, novedad, ya que gritan, lloran, piden perdón, pero en realidad no hay porque alarmarse, porque estas sectas no tienen profundidad, no tienen raíces, de ahí que una vez que pase la novedad su fuerza se irá perdiendo, "tienen una estructura superflua”.

El problema principal, manifiestan los sacerdotes de la región de la zona de estudio, radica en que la gente que se cambia de religión y pasa a las sectas, se somete a las reglas rígidas que les imponen como: no beber, no bailar, no fumar y cuando las rompen y son corridos los "compañeros" chinantecos ya no regresan a la religión Católica: por vergüenza, por pena, el problema, que ven en la comunidad es que la gente se queda sin religión, permaneciendo en un estado anímico, que necesariamente repercute en las formas estructurales comunitarias (Véase Durkheim,1989).

Las sectas religiosas proliferan donde hay desintegración y marginación económica. Pero, además, la multiplicación de las sectas religiosas es la consecuencia de las limitaciones a las libertades políticas. En la medida en que el aparato de Estado prohíbe la libre formación de organizaciones políticas, la única posibilidad de expresión popular que subsiste es la religiosa: frente al control del aparato político, es el aparato religioso que viene a ser el modo principal de expresión para los grupos subalternos..." (Saldaña, 1988:12). En este sentido, la idea de los católicos, "es respetar lo que ordena la Biblia, los 10 mandamiento de la ley de Dios, para que puedan salvarse, pero hacer todo lo que dicen, no nada más predicar y decir a los compañeros que hagan lo que mandan los mandamientos sino ser, como somos, estamos predicando con el ejemplo, eso es ser católicos"18 Y los evangelistas, piden perdón por los pecados, "le piden perdón a los mismos compañeros, por ejemplo, el pastor como le llaman ellos, no tiene ninguna clase de estudios, y a diferencia de los sacerdotes católicos cuentan con 15 o 20 años de estudio, no se puede comparar con el pastor, que es un paisano sólo por el hecho de ponerse de 'pastor' a predicar, a hablar, buscar la manera de engañar, que deje de creer en los mandamientos, que hable de un 'solo Dios, para hacer su grupo de religión.' ${ }^{19}$

17 Cfr El libro de Carlos Fassio El Caminante. En esta obra se describe la vida de Samuel Ruiz, obispo de San Cristóbal de las Casas, Chis, se plantea y analizan estos casos, entre otros, considerando la renovación y la predica de Jesús de la doctrina cristiana.

18 Información oral recabada en la localidad de San Lorenzo Lalana Don Diego, diácono laico de la comunidad.

19 Información recabada en Arroyo Plátano, San Juan Lalana, 1990 
Estrategia de la Iglesia Católica para contrarrestar la proliferación de sectas protestantes en la Chinantla.

La Iglesia nada más orientaba para que no se agregaran a la secta, ya que no estaba bien, y estos grupos están mal aconsejando a la gente. ${ }^{20}$ La Iglesia en su labor de proselitismo hacía por reunir más seguido a los niños y a la gente, fomentar más la participación a la doctrina. Periódicamente están haciendo visitas a las madres para orientarlas, y así inducirlos al mejor camino de la religión. El padre de la comunidad de Arroyo Arenal, anuló el libro que hicieron los del Instituto Lingüístico aquí en la Chinantla, para una nueva versión, primero hizo un análisis a fondo como se redacta un libro en idioma chinanteco, que no lleve la conformación numérica así como lo hizo Rensch. Fue a la ciudad de México, para comprar o mandar hacer una máquina de escribir como él pensaba, adecuada al chinanteco y solicitó ante la Secretaría de Educación Pública, una máquina especial para escribir el chinanteco; sugirió la forma de adaptarla. Sin embargo, ya con anterioridad Rensch mando hacer la máquina para escribir en chinanteco, pero quien la obtuvo de la Secretaría de Educación fue el padre Isidro. Una vez con la máquina adaptada al chinanteco, el padre sacó un nuevo libro. Y ahora inició un curso, para que en sus comunidades aprendan a hablar, escribir y leer bien el idioma chinanteco, de la misma manera "común" como se hace cotidianamente. A esto se antepone que los primeros libros hechos por Rensch, no le permite a la gente aprender a escribir y a leer su propio idioma (el indio inferior fue vencido, y explotado, es ignorante, no tiene capacidad). No obstante la difusión que las diferentes sectas están realizando de los textos bíblicos en idioma chinanteco, el padre Isidro está organizando cursos a fin de que la gente aprenda a escribir y a leer. Yo ya tengo dos cursos, ya fui dos veces a Tuxtepec. ${ }^{21}$

Los sacerdotes y las religiosas que trabajan en la zona tratan de contrarrestar las acciones de las sectas generando una dotación de despensas a precios muy accesibles y de igual manera que las sectas tienen un dispensario médico, el cual es abastecido por las donaciones de otras parroquias de otras entidades (México, DF.), sin embargo, en comparación con la infraestructura y el despliegue económico que vienen haciendo las sectas, estas acciones resultan por demás insignificantes.

20 Véase las declaraciones recientes de los representantes de la iglesia, referentes a la posición de éstos y su postura ante las sectas.

21 Don Diego el diácono laico de la comunidad de San Lorenzo ya ha tomado dos cursos organizados a nivel regional (Área Chinanteca) en Tuxtepec Información obtenida en San Lorenzo, 1990. 


\section{Las Sectas Protestantes, estructura y organización interna}

\section{Caracterización teológica. Fundamentos ideológicos de las sectas}

En México existen aproximadamente de 150 a 200 sectas protestantes (Giménez, 1980 y Excélsior, 1990). Ahora bien, las características más generales de las sectas nos dice Bryan Wilson, son las siguientes: son una asociación voluntaria, membresía que presupone cierta exigencia personal comprobada o sometida a examen por las autoridades del grupo; pretensión de exclusividad, por lo que se sanciona con la expulsión a los que contravienen a la doctrina o preceptos morales u organizativos del grupo; pequeño resto dotados de una luz especial; aspiración a la perfección personal; cualquiera que sea el modo en que ésta se conciba; afirmación real del sacerdocio de todos los creyentes; gran nivel de participación laica; posibilidad de que los miembros expresen voluntariamente su compromiso; indiferencia frente a la sociedad secular y al Estado (Véase a Wilson,1970).

Según Werner Stark las sectas son grupos que se dotan a sí mismos de la estructura y de la organización requerida para administrar la identidad de sus adherente $s$ en función de un conjunto claramente definido de creencias o ideologías, pero además hay que considerar que las sectas presentan un inconformismo frente a las Iglesias denominadas mayoritarias, es decir las sectas constituyen una contracultura, pero que mantienen un sistema unificado de creencias y prácticas relativas a las cosas sagradas, unidas en una estructura moral llamada Iglesia, manifestando el sentido tendiente a la "colectividad". 22

Algunas características que son tomadas en cuenta para definir la secta son: su respuesta al mundo; clase de reacción en las creencias; y, prácticas usuales de sus miembros. Aun cuando esto nos ofrece limitaciones debido a que la clasificación teológica de los sectarios: "limita las posibilidades del estudio comparativo dentro de las diversas tradiciones religiosas; impide el reconocimiento de aspectos importantes del carácter de las sectas; la dosificación derivada de la descripción doctrinal no toma en cuenta debidamente los aspectos de la organización y dinámica de las sectas, además se caracteriza a las sectas en términos normativos" (Robertson, 1980:33 1). Para Bryan Wilson existe la siguiente tipología de las sectas:

22 Wemer Stark. Véase a Gilberto Giménez. La identidad social o el retorno del sujeto en sociología, en Revista Mexicana de Sociología. La proliferación de identidades grupa les de pequeña escala y de orientación anti-institucional (v.g., el fenómeno de las sectas), y el despertar nativista de las identidades étnicas y sub-nacionales que se creían desaparecidos o debilitados. En lo que Maffesoli llama "tendencia a la neotribalización” citado de Michel Maffesoli. Le temps des tribus. París, 1988 


\section{Secta Conversionista}

Sugiere que el mundo está corrompido porque el hombre está corrompido. Es típica del fundamentalismo cristiano evangélico. Interpretan las escrituras literalmente y sus miembros tienden a considerar esta relación en forma literal. Se liga al desarrollo del individualismo $\sim$ esto constituye tal vez la condición sine qua non de su aparición. ${ }^{23}$ "Su actividad es principalmente una ceremonia de reavivación y la plegaria pública masiva (camps meetings). Como ya se dijo expresan en términos emocionales la relación entre el individuo y el Salvador, considerando a éste como un superhombre que sufre, los textos que emplean predican el evangelio por todo el mundo. Se consideran dentro de este tipo: el ejército de salvación; las asambleas de Dios, movimientos pentecostales y algunas sectas evangélicas independientes" (Robertson, 1980:333).

\section{Secta Revolucionaria}

Se reconoce el tipo revolucionario en los movimientos escatológicos de la tradición cristiana. "Los textos bíblicos preferidos en estos círculos son directamente escatológicos o bien visiones obscuras tomadas de libros proféticos que pueden interpretarse como pronósticos aplicables al periodo actual" (Robertson, 1980: 333). La actitud hacia el mundo es la de destruir el orden social. Tiende a una menor moralización, pues considera la realización de un plan divino. Su conversión se considera como un hecho causal y gradual hasta que se convenza el individuo. ${ }^{24}$ Cuando se institucionaliza se mantiene en una pureza doctrinal. Sus reuniones son carentes de emoción sólo para alabar a Dios, al que ven como autócrata, como líder que se impone al progreso del universo. Los miembros se consideran instrumentos de Dios. Entre este tipo se cuenta a Los Adventistas, Los Testigos de Jehová, los Mormones los Cristadelfos y los Hermanos de la Quinta Monarquía” (Wilson, 1970:125).

23 No se interesan por los programas de reforma social y/o por una solución política de los problemas sociales, se considera activamente hostial hacia ellos. Se pronuncia por la conversión de la población Maneja juicios muy moralizadores (los revivals) hacia el hombre y los acontecimientos, ya que se piensa que el hombre es responsable de sus acciones. Tiende hacia las explicaciones causales. como la influencia, el ambiente sobre el comportamiento 24 Constituye el principal tema de debate entre la secta y la sociedad más amplia Esperan un nuevo orden bajo la dirección de Dios Son hostiles a la reforma social y a la conversión instantánea. Explica el mundo de manera determinista Comparan entre pronósticos de las sectas (exégesis profética) y acontecimientos contemporáneos 


\section{Sectas Introversionistas}

Esta secta se repliega en el mundo de la interioridad espiritual como valores de la seguridad interior a través de la santidad y la perfección, el vivir apartados del mundo. Sus reuniones se caracterizan por los salmos. Se considera los movimientos de santidad y los pietistas europeos del siglo XVIII son fiel imagen de esta secta. Este tipo de secta al igual que la manipulacionista no tiende a desarrollarse en las comunidades indígenas. ${ }^{25}(29)$

\section{Sectas Utópicas}

Son las que se aíslan del mundo formando comunas y colonias aisladas. Persiguen la idea utópica de reconstruir un nuevo mundo sobre una base comunitaria o comunal. Ejemplo de estas sectas son

Los Menonitas, Los Tolstoyanos, La Comunidad de Oneida y Amana, Los Tembladores y otros grupos semejantes. ${ }^{26}$

\section{Secta Gnósticas o Manipulacionistas}

Tienen una visión espiritual y etérea de los fines culturales de la sociedad global, los valores de esta secta se centran como único medio verdadero para adquirir salud, riqueza, felicidad y prestigio social, los que alcanzarán mediante este conocimiento. Algunos grupos de este modelo son los de Ciencia Cristiana, Cientología o Iglesia de la Nueva Comprensión (Dianética), Rosacruces, Unitarios, Psiquianos, etcétera. ${ }^{27}$

25 Se caracteriza por un predominio del individualismo religioso en donde la comunidad es sólo un soporte del individuo (el remanente de escogidos). Conciben a un Espíritu Santo, la relación entre pecador y salvador es menor.

26 Es más radical que la secta reformista, menos violenta que la revolucionaria y más constructiva a nivel social que la conversionista. Si pertenencen al cristianismo se basan en la comunidad pnmitiva de Jerusalén.

27 Creen que el movimiento puede lograr el cambio mediante el conocimiento iniciático que distingue a sus adeptos. Son grupos reducidos, e impersonal, frecuentemente sincretista, no manifiestan interés por la escatología, difunden métodos esotéricos y para ellos no es tan importante la conversión, dado que sólo puede surgir cuando el pensamiento metafísíco haya penetrado en las tradiciones religiosas y filosóficas de una sociedad. Cfr. Roland Robetson. Una tipología de las sectas, en Sociología de la Religión. 


\section{Sectas Taumatúrgicas}

Dentro del cristianismo son movimientos que consideran los hechos sobrenaturales a su vida, en éstos caen los espiritistas que utilizan métodos de carácter taumatúrgico o sobrenatural. Fieles representantes son los grupos y las Iglesias Espiritualistas. ${ }^{28}$

\section{Sectas Reformistas}

Originalmente revolucionaria, con una actitud introversionista. Son poseedores de un sentido de identidad, maneja el papel de la conciencia social Los Cuáqueros y los Cristadelfos podemos considerarlos dentro de este grupo. ${ }^{29}$

En México las sectas que más predominan son las Conversionistas: Pentecostales; Y las Revolucionarias Adventistas, a su vez el pentecostalismo se subdivide en:

1. movimiento Pentecostés, el que engloba a las Iglesias y sectas pentecostales clásicas.

2. Movimiento Carismático

3. Pentecostismo Independiente de numerosas Iglesias del tercer mundo "Iglesias Indígenas de Origen Autóctono" del pentecostismo. ${ }^{30}$

La corriente que llega a México, corresponde a la primera subdivisión Y por lo tanto la influencia que se deja sentir es directamente norteamericana. Las sectas revolucionarias/Adventistas están re-presentadas en el sureste principalmente, parece probable que en las sociedades menos avanzadas sean limitadas las posibilidades de respuesta al mundo exterior, y que las sectas constituyan posibilidades de respuesta original en las sociedades preágrafas. Esto permite considerables elementos de fantasía; las sectas que abundan en las comunidades indígenas caracterizan la religión y la magia primitiva, no hay que olvidar que los curanderos son parte de la tradición taumatúrgica del

28 Consideran que estando en contacto con los espíritus buscan algunas transformaciones y realizan milagros o curaciones extraordinarias, dando alivio a males físicos y mentales, se encuentra cerca de la magia Su forma de culto es la 'sección' Cfr Alain Woodrow. Las nuevas sectas

29 Este tipo de sectas estudia al mundo para incorporarse a él por sus buenas acciones, ocupan un lugar en el mundo sin ser parte de él ni mancharse de sus impurezas Su doctrina es moderada. Esta categpria reviste la importancia que parecería tener para el estudio de las transformaciones de las sectas cuando la estructura persiste aunque se modifique la respuesta al mundo exterior. Crf Roland Robertson. Op cit.

30 La corriente que llega a México no corresponde a la tercera subdivisión, que por pertenecer al Tercer Mundo nos correspondería. 
propio cristianismo, y que se desarrollan como una respuesta al cambio social y al propio deterioro de la cultura tradicional afectada por el exterior, por medio de la introducción de ideologías nuevas que se convierten en fuente de ideas y prácticas religiosas accesibles a los movimientos puramente "nativos” ocupan el primer lugar los Adventistas del Séptimo Día, seguidos por los ,Testigos de Jehová y los Mormones o Iglesia de los Santos de los Ultimos Días.

\section{Denominación y Pertenencia a la Iglesia Matriz o Corriente Ideológica}

Desde un punto de vista sociológico al referimos a los grupos religiosos minoritarios en México, no todo lo no católico es protestante o evangelista, no obstante el protestantismo es hoy por hoy una realidad ${ }^{31}$ con un ritmo de crecimiento acelerado y relativamente estable y con una estadía en las comunidades, pues sólo el estado de Oaxaca cuenta con el 22\% de feligreses (CONAFE, 1987). En casi todos los pueblos donde se encuentran se puede constatar los avances de este fenómeno religioso, en donde los católicos se han ido convirtiendo paulatinamente en una minoría; ;2 así el término secta lo vamos a entender de acuerdo a la caracterizado que hace Weber en Sociología de la Religión, como un grupo minoritario, con una doctrina particular, como una separación de la mayoría, "una tendencia a formar pequeños grupos en tomo a una ideología común que aísla a sus miembros y les quita toda opinión crítica y los doblega frente a una autoridad casi omnipotente" (Careaga, 1984:4 y Wilson,1970), un alto nivel de integración, voluntaria y sin gozar del favor del Estado.

\section{Secta de los Mormones o Iglesia de los Santos de los Últimos Días}

José Smith, joven que no estaba conforme con las enseñanzas de las Iglesias protestantes de Estados Unidos, asume el papel del líder en el orden de la organización y del gobierno e incluso la doctrina. El mormonismo ${ }^{33}$ da prin-

31 Y constituye uno de los fenómenos a clarificar como parte de la Sociología de la Religión

32 Como observamos en el estado de Tabasco Cfr CONAFE Encuesta sobre la penetración de grupos religiosos en comunidades con cursos comunitarios, en Excélsior 1988-1991 (diversas notas y reportajes); también véase a Gilberto Giménez. Op cit

33 Kimbal La expansión es la tarea prioritaria de la iglesia Pese a su caractér tipicamente norteamericano ésta se haya establecida en 75 países y cuenta con 3 millones y medio de fieles, 10 mil de los cuales se hallan en Francia Gracias por lo demás a la actividad de más de 24000 jóvenes de EU que sirven como misioneros por todo el mundo, la iglesia aumenta en 
cipalmente importancia al matrimonio, no obstante, la poligamia no es una doctrina lateral o marginal, es el medio mismo del perfeccionamiento y exaltación para alcanzar la divinidad. La manera de cumplir con este deber es tener muchas esposas. Los mormones afirman que la Biblia está incompleta, pues no menciona a la Tribu de Israel que pasó a América. El sacerdocio de la Iglesia es el gobierno de Dios en la tierra. Tienen obispos, consejeros y secretarios de barrio.". ${ }^{4}$ Destacan su bondad, espíritu de servicio, trabajo disciplina. No fuman, no ingieren bebidas embriagantes ni refrescos de cola ni café, y condenan el libertinaje sexual.

\section{Secta Testigos de Jehová. ${ }^{35}$}

"En México se denomina Atalayas a los Testigos de Jehová. ${ }^{36}$ Cada creyente es un ministro $y$ por ende un misionero. No desmayan ante el desprecio por el rechazo de la gente..., el hermano pionero o es un verdadero deposito de citas, los norteamericanos que iniciaron este trabajo se han preocupado por la formación de dirigentes nacionales. Toda la literatura sigue siendo preparada en Nueva York, sede de la Torre del Vigia" (Macin, 1988:50).

El nombre de "testigos" alude a la misión que se atribuye la secta de dar testimonio del verdadero nombre del Señor Jehová, revelad' en el "Antiguo Testamento", olvidado por la "cristiandad oficial” y obscurecido por Satán.

100 mil nuevos convertidos cada año; no decaen en su ardor, y durante dos o tres años perseveran incansables en evangelizar las más remotas regiones procurando ganar más adeptos para su extraña religión.

34 Auncuando en el libro del Monnón se enseña que existe un solo Dios en otros escritos admite que hay tres, negando la unidad del Padre, el hijo y el Espíritu santo. Hacen hincapié en que todos los fieles llegan a ser dioses, por lo cual han caldo en el pietismo. Todos los dioses, inclusive Jesucristo y su padre, tienen cuerpos gloriosos de carne y hueso Únicamente el espíritu no lo tiene y está presente en todo el universo Los dioses han sido humanos, tuvieron esposas y procrearon hijos Los hijos de estas uniones son almas que esperan nacer en el mundo. Si oyen la doctrina mormona, la aceptan y la cumplen, después de la muerte serán dioses. Raúl Macín El protestantismo en México. pp. 52.

35 Se consideran asi mismo cristianos y continuadores de los reformadores protestantes del siglo XVI Trabajan actualmente en 159 países, esta considerada como la secta de mayor crecimiento en América Su cede se encuentra en Brooklyn, NY. En 1889 se incorporaron como organización internacional: la Sociedad de Tratados de la Torre del Vigia o de Sión; la Asociación Internacional de Estudiantes de la Biblia; el Reino Teocrático; el Púlpito del Pueblo; la Aurora Milenaria; el Russellismo; la Sociedad Bíblica (es un miembro asociado al I LV) y el Tratado de la Torre de Vigía. Todas estas asociaciones agrupadas tomaron el nombre oficial de Testigos de Jehová a partir de 1931

36 Secta Revolucionaria. Elitista y agresiva por excelencia 
El Espíritu Santo no es una persona, sino una emanación de Dios: el Espíritu Santo de Jehová es una fuerza activa, invisible; no únicamente el poder que reside en si mismo sino Una energía cuando se proyecta fuera de sí para cumplir su voluntad y propósito. Tienen su propia versión de la Biblia, textos escatológicos o bien visiones oscuras tomadas de libros proféticos interpretados como pronósticos aplicables al período actual, las cuales hay que tomar las al pie de la letra, distintas a las utilizadas por las denominaciones cristianas. La doctrina de esta secta "constituye una mezcla curiosa de teología liberal (Cristo no es Dios), de exégesis literal (todas las citas contenidas en la Biblia son explicadas minuciosamente) y de un radicalismo agresivo (oposición total a toda autoridad civil o religiosa y a todas las Iglesias y sectas). El grupo espera para un futuro próximo, aunque indefinido, la batalla final que opondrá las fuerzas de Jehová - Dios a las del diablo (batalla de Armagedón). Los buenos saldrán victoriosos y Satán será encadenado por mil años. Durante este tiempo, los 'testigos' educaran a la humanidad (incluidos los muertos y los resucitados) para ofrecerle una última oportunidad. Pero Satán, liberado al fm del milenio, tratará de seducir nuevamente a los hombres. Los que lo siguieren serán definitivamente aniquilados con él. Tal será su castigo, porque no existe el infierno. Por fin se instaurará aquí en la tierra el paraíso perdido y reencontrado" (citado por Giménez,1989:35). La muerte es un período de absoluta inexistencia; el espíritu resucitará el día final; durante el milenio habrá oportunidad de arrepentimiento para los condenados, que tendrán cien años para decidirse.

\section{Secta Adventistas del Séptimo Día o Sabáticos ${ }^{37}$}

Los Adventistas del Séptimo Día (Revolucionaria), movimiento religioso iniciado en Estados Unidos, secta milenaria fundada a mediados del siglo XVII. Un campesino de Pennsylvania, aunque domiciliado en Nueva York, adscrito a la Iglesia bautista, sintió un reavivamiento religioso y se aplicó al es-

37 "Actualmente hay en el mundo unos dos millones de miembros bautizados. que se reúnen en unas 17000 iglesias; alrededor de 30000 escuelas sabáticas. reúnen unos 3 millones de alumnos $\mathrm{El}$ número de personas que dedican todo su tiempo a la obra es de cerca de 70 000; 8000 son pastores ordenados. Los colegios son unos 5000 Asisten a ellos unos 400 000 alumnos La iglesia adventista se halla establecida en 190 países y la predicación se hace en 940 idiomas hay 291 hospitales, sanatorios, dispensarios y clínicas". CELAM. pp. 98. En México tiene su sede en Uxmal365 en el Distrito Federal. se trata de un templo grande y bien acondicionado, con oficinas anexas. En la ciudad de México tiene otras dos iglesias, en Sadi Carnot 122 y en Agricultura 752. Se han significado por su apoyo a la Sociedad Bíblica Mexicana, son los mayores aportantes quiénes venden ejemplares de la Biblia 
tudio de la Biblia, y en especial al libro del Apocalipsis ${ }^{38}$ y los libros de "concordancia bíblicas" William Miller y posteriormente una seguidora de sus ideas Elena White, retorna la doctrina de éste y reorganizan a los seguidores y que más tarde llamaron "Iglesia de los Adventistas del Séptimo Día”. El mundo es malo y perverso, predican una transformación de origen sobrenatural, considerando los movimientos escatológicos o milenario $s$ inspirados en la tradición apocalíptica, Su día de culto y adoración a Dios es el sábado, en el que invocan al Todopoderoso, pues la Biblia no conoce otro, leen la Biblia, que tienen como única regla de fe. Las escrituras se interpretan a la luz de los numerosos escritos de la Sra. White, favorecida durante su larga vida con visiones y revelaciones. Oran de rodillas, escuchan el sermón del pastor y cantan himnos; las mujeres desempañan varios oficios, menos los de pastor, al igual que los ancianos; y cada tres meses, previo el lavatorio de los pies celebran la Cena del Señor, o sea la comunión, durante la cual imparten un trozo de pan sin levadura y un vasito de jugo de uva. El bautismo produce la muerte del pecado y la resurrección de quien lo recibe a una vida nueva en el amor de Dios.

Sectas Pentecostales (Asambleas de Dios, La Iglesia de Dios en Cristo, la Iglesia de Dios, la Iglesia interna del evangelio, la Misión evangélica de la fé, la Iglesia del Nazareno)

En la región chinanteca, al igual que en el resto del país, los que predominan son los Evangélicos-Pentecostales que son los que más contribuyen al crecimiento del conjunto de las sectas, ${ }^{39}$ el pentecostismo constituye un movimiento religioso de una gran difusión a nivel mundial. Para evitar lamentables confusiones, hay que comenzar por distinguir dentro del pentecostalismo tres corrientes principales:

Primera, el "Movimiento Pentecostés propiamente dicho que engloba a las Iglesias y sectas Pentecostales Clásicas, en gran parte de origen americano (incluyendo sus filiales misioneras);

Segunda, el llamado "Movimiento Carismático" dentro de las Iglesias tradicionales, incluida la Católica (también con sus respectivas Iglesias misioneras), ${ }^{40} \mathrm{y}$

38 Último Libro del Nuevo Testamento.

$3970 \%$ del total de creyentes son protestantes Gilberto Giménez. Op cit. pp. 42. Véase también todas las expulsiones de las comunidades en Chiapas en los últimos años.

40 Los movimientos carismáticos están constituidos por grupos que han aceptado algunos elementos de la espiritualidad Pentecostés, pero sin abandonar sus iglesias tradicionales Estos 
Tercera, el Pentecostismo independiente de numerosas Iglesias del tercer mundo englobadas por David S. Barret bajo la denominación genérica de "Iglesias Indígenas de Origen Autóctono (Indigenous Non-White Churches)" 41

Los pentecostalismos mexicanos son parte de la primera corriente y son de carácter casi exclusivamente americano y auto sostenidas económicamente. Derivados del movimiento de "Los Angeles" (1906), como parte de la culminación del movimiento de santificación en Estados Unidos, como un llamado a la santidad y a la actitud puritana ante la vida. Las Iglesias Pentecostales en México han sido creadas por misioneros del IL V en las comunidades indígenas, también por braseros que regresando de los $\mathrm{E}$. $\mathrm{U}$.

\section{Sectas Bautistas}

La Iglesia Evangélica Bautista es de las primeras en cruzar el ancho mar. Se considera que siempre ha existido en el mundo un grupo de bautistas anónimos, los que han servido de encadenamiento hasta llegar a la organización visible de la Iglesia en siglo XVII, trabajan de manera especial entre las gentes más sencillas, ${ }^{42}$ "la población... no está evangelizada... la meta de la evangelización neotestamentaria no es tan sólo el ganar almas... sino el establecimiento y crecimiento de sus Iglesias locales" (CELAM,1989:88).

En 1962 se instaló en La Haya, la sede central de un movimiento religioso "inspirados" por la "Fama Fraternitatis", muchos comenzaron a organizar

grupos argumentan generalmente de este modo: "desde que somos carismáticos comprendemos mejor nuestra propia tradición (católica, reformada, anglicana, luterana, etcétera), y no sentimos necesidad alguna de revisar críticamente las posiciones teológicas de nuestra iglesia" La corriente carismática queda fuera de nuestra perspectiva en el presente estudio, pero puede consultarse últimamente a este respecto, entre otros a Francoise Van Der Mensbrugghe. Le, l7Jouvement charismatique Ed. Labor et Fides Ginebra, 1981.

41 Barret designa de este modo a las iglesias del Tercer Mundo que surgieron independientemente de las obras misioneras de origen occidental y que reúnen en su seno sólo a poblaciones no blancas Numerosas Iglesias de Africa, de América Latina y del Caribe pertenecen a esta categoría que, según Barret, tiene consistencia propia. Cfr. David S Barret. World Christian Enciclopedia. Nairobi, 1982. (citado por W. J Hollenweger en su prefacio al libro de Daniel Brandt-Bessire. Aux Sources de la Spiritualité Pentecostiste Ed Labor et Fides Ginebra, 1986. pp.13).

42 En tiempos de la reforma, fue el párroco Baltazar Hubmier, quien proclamó la libertad absoluta. Son originarios de Inglaterra, expandiéndose por Europa, E U Y posteriormente al resto del mundo Se caracterizan por ser grupos espontáneos surgidos aquí y allá. 
capítulos de hermanos rosacruces. Ésta es la fuente remota de tales movimientos que actualmente se presentan como "Rosacruz", en nuestro continente. En la región de estudio pudimos percatamos de la existencia (o el paso por la Chinantla) de este grupo religioso llamado de Los Rosacruces, "están allí, y propagan que el hombre cree en Dios, y no muere, este grupo religioso creen en todo y hasta hacen milagros". ${ }^{43}$ También se consideran como un equipo de "científicos" que solo paso por la región. Sin embargo, a lo largo de la investigación no se encontró la presencia de éstos.

\section{La Luz del Mundo}

Tienen su sede en Guadalajara donde sus miembros han formado una colonia. Se caracterizan por su honestidad, trabajo, disciplina y disposición a reconocer en los gobernantes civiles una expresión de la voluntad de Dios. Son unos 40 mil. ${ }^{44}$

\section{Formas de Asentamiento y Comportamiento en la Comunidad}

En la comunidad de Arroyo Blanco, agencia del municipio de San Juan Lalana, existen tres grupos religiosos diferentes: a) El Pentecostés; b) El Príncipe de Paz; y c) Los Adventistas.

La secta Príncipe de Paz empezó a establecerse en la comunidad, toda vez que la gente salía a visitar los pueblos circunvecinos, de la misma región, aquéllas donde se encontraba un pastor, como Cantarito, que es una comunidad que está antes de llegar a Arroyo Blanco, las gentes iban a esta comuni-

43 Información directa proporcionada por Don Moisés Sevilla, Arroyo Blanco, San Juan Lalana, 1989.

44 Su fundador y profeta fue Aarón Joaquín, sucedidoa su muerte, por Samuel Joaquín. Tienen templos en las principales ciudades, los más grandes son los de Guadalajara y México No preparan a sus sacerdotes, pues según ellos toda instrucción viene de Dios. Celebran un culto por la mañana y otro por la tarde.Las mujeres visten de largo, no se maquillan, son recatadas y se les exige sumisión al marido Todos guardan el día del Señor, creen en la inspiración y en las revelaciones, se confiesan y dicen ser la luz del mundo. Han intentado rescatar los valores del sacerdocio tal como se decribe en la Biblia. En agosto de todos los años se realiza una peregrinación a Guadalajara, el lugar santo, en la que participan unos 10 mil creyentes del país y del extranjero El profeta preside las actividades, nombra a los pastores y alas diaconistas y es la máxima autoridad en la colonia. hay ya una congregación en Roma y otra en el sur de Estados Unidos Raúl Macín. Op cit. pp52. 
dad, así poco a poco se aumentó el número de los que entraron a este nuevo grupo religioso. Llegaron aproximadamente en 1980, con un predicador, y se quedaron aquí. No sabemos muy bien su finalidad. Esta comunidad cuenta con una población de 60 jefes de familia, de los cuales, entre seis y siete jefes de familia pertenecen a la "religión" Príncipe de Paz.

Las formas del culto en esta comunidad las realizan mediante las ceremonias en el templo: cada una de las "religiones" tanto la Pentecostés, La Príncipe de Paz y La Adventista tienen su templo en la comunidad. El calendario de reuniones o ceremonias cotidianas, para los Príncipes de Paz es por lo general los domingos para la celebración del culto.

\section{Área de Influencia de la Pastoral Sectaria}

Arroyo Tomate fue la comunidad en donde primeramente se establecieron los misioneros del IL V, a partir de aquí se empezó a formar los grupos sectarios, en donde a través de las medicinas que les regalaban empezaron a llegar de otras comunidades para que les ayudaran a curar a sus familiares enfermos, o les obsequiaran los medicamentos ya que económicamente ellos no podían cubrir. En esa interacción, y conjuntamente con la formación de los primeros grupos se inició la influencia en otras comunidades, primero las más cercanas, y estas a su vez servían de difusión a otras cercanas a ellas, iniciando así la cadena de conversos y la entrada de las sectas, en donde la "ayuda médica" sirvió como gancho. En la actualidad se da a través de Visión Mundial, con todo tipo de ayuda "comunitaria".

\section{Contacto y Establecimiento de las Sectas en la Comunidad}

Al hablar de las formas de contacto y establecimiento de las sectas, en la Chinantla es preciso referimos a Calvin Rensch que está catalogado como el pionero de las sectas de la zona chinanteca de la Lalana.

La llegada de los primeros misioneros del IL V a la comunidad de Arroyo Tomate, fue en el año de 1954, primer lugar donde se establecieron Calvin y Carolyn Rensch y Robert Mugele y su esposa fueron los primeros que vinieron. ${ }^{45}$ Primero recorrió diversos lugares pero no le gustaba como hablaban el idioma, entró a la Chinantla por Playa Vicente, llegó a caballo, a pie, por San Lorenzo, reconoció el terreno estuvieron un tiempo en el Arenal, donde empezó a familiarizarse con el idioma, posteriormente visita Arroyo Tomate, 45 Robert Mugele, estaba ubicado en El Arenal, una comunidad cercana a Arroyo Tomate, sin embargo, fue trasladado, quedando solamente Rensch. 
donde se instaló. Dijo que se quedaba a vivir, ya que aquí no hablaban español, la gente era monolingüe, todos era completamente analfabetos sólo dos o tres hablaban, poquito en castellano, todos en su dialecto. El idioma que los miembros del IL V hablaban a su llegada era básicamente el inglés, sólo hablaban poco de español, en México terminó de aprenderlo. Al poco tiempo y con ayuda de José se comunicaron en Chinanteco, sin embargo esto no fue ningún impedimento para que ellos pudieran comunicarse y aprender en tan solo dos meses el idioma chinanteco.

Cuando Rensch empezó a tener contacto directo con los pobladores, llevaba consigo medicamentos. Este fue el instrumento idóneo que le permitió entrar fácilmente a la población. Tenía nociones elementales de medicina; curaba a la gente auxiliándose con un manual de medicina práctica, para personas no versadas en esta ciencia. No era médico pero curaba a la gente. Asumía el "papel” de médico general; y por lo tanto el de dentista. En suma aplicaba el "Desarrollo de la Comunidad".

El dinero que llega de Visión Mundial se maneja mediante fondos económicos que depositan en una cuenta bancaria, desde México. El facilitador, y/o la auxiliar de enfermería encargados de la zona retiran de la cuenta el dinero necesario para los programas. La ayuda es de tres tipos: a) materiales escolares; b) ropa; y c) dinero en efectivo a los padres para la construcción de una vivienda digna para los niños. Además de este tipo de ayuda, reciben una derrama económica en "programas de desarrollo para la comunidad" como la construcción de puentes, electricidad, asoleadores de café, semillas e instrumentos para la labranza, entre otros; este tipo de "ayuda" que las sectas realizan en las comunidades despierta intereses comunes de la población, conformándose así los nuevos grupos religiosos.

En la zona Chinanteca de Lalana los portavoces de la religión llegaron en los años cincuenta y eran de origen Norteamericano. Se introdujeron en las comunidades regalando medicinas, que aún hace dos tres años volvían cada fin de año y traían muchas cosas Y repartían medicina, y Biblias, también juguetes “ y no sé que tanto, pero nada más una vez al año". El centro de salud en Arroyo Tomate es hoy lo que era ayer, la casa de los lingüistas del IL V. En la actualidad es manejado por otro grupo de la misma denominación, como es Visión Mundial. El costo total de los gastos que genera el centro de salud es absorbido por Visión Mundial, la que provee de medicamentos a las comunidades, aproximadamente cada tres meses se recorre toda la zona de este municipio las llevan a vender a precios baratos ${ }^{46}$ lo que les permite

46 Regalados El costo de la consulta con todo y medicamento es de $\$ 50000$ pesos, 1989 1990. 
una fácil entrada y desarrollar su labor de proselitismo, siendo la condición para tener derecho a los servicios de salud y medicamentos, ser miembro de una secta de las que promueve esta "venerable institución", cuyas formas de introducción se da a través de los pastores que se establecen en las comunidades; aprenden el idioma conocen sus costumbres, les enseñan como cultivar, como hacer pozos y medidas de salubridad. El aspecto principal con que se ganan adeptos es con la medicina y ahora con una nueva modalidad, el "apadrinamiento" de sus hijos. Los protestantes presentan a los indígenas la posibilidad de sanar sus enfermedades y esto, en condiciones de miseria e insalubridad se vuelve muy apreciado.

Expansión Regional de las Sectas. El nacimiento de grupos sectarios en comunidades vecinas

Con la presencia del IL V, en las comunidades aparecieron muchas otras sectas, ${ }^{47}$ de origen Norteamericano. Algunas sumamente agresivas. "Los misioneros protestantes llegaron por primera vez a la región y desde entonces ha habido siempre representantes del IL V de los Wycliffe Bible Translator. El interés primordial de estas misiones ha sido la evangelización de los indios y salvo escasas excepciones, han hecho poco para promover el bienestar material de los indígenas" (Clai,1987:74). No cabe duda que las sectas protestantes se han expandido. Gilberto Giménez considera que para el año dos mil el $50 \%$ de los pobladores del sureste serán católicos y el otro tanto será protestante. En la comunidad de Arroyo Plátano coexisten: Católicos; Sabáticos; Pentecostés; Rosacruces, y la Príncipe de Paz que se encuentra dispersa por todo el municipio, sobresale la Esperanza Y Arroyo Tomate.

Se ha agrupado a este movimiento derivado del protestantismo en las siguientes "sectas" que son las que más sobresalen: Testigos de Jehová o Russellistas; la Iglesia de los Santos de los Últimos Días o Mormones; los Adventistas o Sabáticos; los Unitarios; La Ciencia Cristiana, los Espiritualistas; la Luz del Mundo, los Moon, los Evangelistas; los Krishna; los Metodistas; la Nueva Jerusalén; los Bautistas; los Presbiterianos; el Evangelio Completo; la Congregación de Dios; la Iglesia del Verbo; los Cuáqueros Niños de Dios; los Príncipe de Paz, los Rosacruces, la Ervagedón y algunos movimientos inspirados en el pentecostalismo. Es importante destacar que no se da una precisión en la nomenclatura, por lo que se presta a una confusión entre secta

47 Denominación bajo la cual la sociología moderna ha agrupado a los movimientos religiosos derivados del protestantismo, que se originaron en el siglo XIX Y proliferan en el XX 
y las Iglesias o denominaciones "históricas", como son los Bautistas, los Metodistas, los Presbiteriano s, y los Congregacionalistas.

Si bien es cierto surgieron del movimiento de restauración de estas Iglesias protestantes, los estudiosos de la religión no los consideran como protestantes, por sus doctrinas contrarias al evangelio de Jesús, las características de su trabajo misionero y la extraña mezcla que han hecho de la ideología religiosa con la política, no pueden ser considerados como protestantes. Además ellos mismos rechazan el ser identificados como tales.

En un mismo pueblo se encuentran hasta dos o tres sectas distintas con 2 templos y 2 pastores. Son los casos concretos de la comunidad de San Juan Evangelista: en donde se encuentran las siguientes sectas: los Príncipe de Paz, los Pentecostés, y los Adventistas. En una secta utilizan la medicina y en la otra no. Primero llegó la Pentecostés, luego los Adventistas, y casi al igual que ésta la Príncipe de Paz. En la actualidad, en la comunidad de Arroyo Blanco están entrando los Testigos de Jehová, mediante la visita constante de una maestra jubilada que trata de convencer a la gente con quién trata frecuentemente, a convertirse en un adepto de esta secta. En las comunidades de la Esperanza y Yogope, existen hasta cinco sectas distintas.

En el municipio de San Juan Lalana se encuentran distribuidas de acuerdo al siguiente cuadro:

\section{Distribución de las Sectas ,Protestantes en el Municipio de San Juan Lalaca. Oaxaca}

$\begin{array}{ll}\text { Nombre Comunidad } & \text { Nombre Secta } \\ \text { La Esperanza } & \text { Principe de Paz, Evangelistas Pentecostés, Sabáticos } \\ \text { Arroyo Tomate } & \text { Pentecostés, Sabáticos (Rosacruz) } \\ \text { Arroyo Arena } & \text { Pentecostales } \\ \text { Arroyo Lumbre } & \text { Sabáticos, Evangelistas, principalmente Principe de Paz } \\ \text { Zaragoza o Cantarito } & \text { Principe de Paz, Sabáticos y Pentecostés } \\ \text { Río Manzo } & \text { Sabáticos } \\ \text { Arroyo Mango } & \text { Pentecostés y Evangelistas } \\ \text { Arroyo Blanco } & \text { Sabáticos } \\ \text { Yogope } & \text { Sabáticos } \\ \text { Arroyo Plátano } & \text { Sabáticos } \\ \text { San Jorge } & \text { Evangelistas y Sabáticos } \\ \text { Santa Cecilia } & \text { Evangelistas y Sabáticos } \\ \text { Santa Rosa } & \text { Evangelistas } \\ \text { San Gabriel } & \text { Evangelistas }\end{array}$


Convergencia Revista de Ciencias Sociales, núm. 14, 1997, Universidad Autónoma del Estado de México

San Juan Evangelista Evangelistas, Ervaged6n y Pentecostés

San Juan Lalana(Cabecera) Evangelistas y Sabáticos

San Isidro Arena Pentecostés

San Lorenzo Pentecostés y Evangelistas (expulsadas de la comunidad)

Fuente: Investigación Directa. 1989-1990

\section{Organización de las Sectas y el Trabajo Misionero Proselitista}

Las sectas protestantes tienen su coordinación a nivel internacional, sin embargo, en la zona chinanteca de Lalana, éstas surgen mediante el IL V ya que éste apareció en la comunidad antes que las sectas y ambas tienen un área de influencia internacional y como toda estructura organizacional debe tener sus coordinadoras, tanto a nivel internacional, nacional, regional y local, así como sus respectivas funciones en sus diferentes niveles, además de contar con una burocracia abundante. Ésta en los pueblos que visitamos, tiene una estructura muy simple que son: los pastores y los hermanos, a su vez los misioneros evangelizan tanto a hombres y mujeres, sin importar la edad, así como a los niños, las sectas no sólo intervienen en el plano religioso, sino además dan servicio a la comunidad como es en el área de salud y educación. Visión Mundial presenta sus oficinas en Córdoba, Ver.; ${ }^{48}$ Veracruz, Ver.; Tuxtepec, Oax.; que son las oficinas regionales con las que se tiene contacto directamente, ya que a través de ellas es como se abastecen de medicamentos y materiales para la construcción, así como de las dotaciones de despensas, útiles escolares, ropa y juguetes para los niños. Las oficinas centrales coordinadoras se encuentran en la ciudad de México. A nivel Internacional, la sede es en Estados Unidos y Canadá.

Visión Mundial cubre los gastos de los auxiliares de médico y enfermeras (además del personal como supervisores, beneficiadores, ingenieros, doctores y demás personal que recorren las comunidades) "Trabajo para Visión Mundial," me paga un sueldo, 150 semanal, los auxiliares, no sé cuánto sacan, pero más o menos en esto, porque los muchachos son los que llevan el control del dinero, porque a veces estoy dando consulta, estamos arriba de 20,000 la semana, casi regalan la medicina, ya que sólo se cobra la consulta, los medicamentos no. ${ }^{50}$

48 Durante el último periodo de la investigación, las oficinas de Visión Mundial ubicadas en Córdoba, fueron trasladadas a la ciudad de Veracruz.

$49 \mathrm{Al}$ realizar el servicio Social de la Secretaría de Salud fui asignada a la comunidad de Arroyo Tomate, fue ahí que me contrató Visión Mundial como auxiliar de enfermera. 50 Información proporcionada por una enfermera de Visión Mundial, Arroyo Plátano 


\section{Símbolos y Asociaciones de lo Real con el Culto y el Sistema de Creen- cias de la Secta}

Es importante destacar que el comportamiento sectario es retomado del movimiento de restauración de los Metodistas, demostrando en primer lugar la disciplina de la fuerza de trabajo basada en el comportamiento irracional en donde el juego, el alcohol y la pereza obstruyen el logro de la salvación. Este tipo de comportamiento dócil, ofrece una compensación religiosa por las privaciones y la rutina de la vida en conversiones emocionales, rituales colectivos y camaradería en la templo. Dios reconoce no la supe-ración de la moralidad terrena, sino precisamente el cumplimiento en el mundo de los deberes que a cada cual impone su posición que ocupa en la vida, y que por lo mismo se convierte para él en "profesión".

Cuando algún miembro de la secta comete la maldad, cuando cometen adulterio lo sacan del templo, lo expulsan, lo corren de la secta. Las autoridades sectarias deben de seguir al pie de la letra los reglamentos internos que rijan la organización, de no cumplirse estos requisitos, se les expulsa de la secta a la que pertenezcan: "Que el hombre y Dios tienen que trabajar juntos para construir un mundo decente: que no existe situación tan mala para el hombre que con la ayuda de Dios no pueda hacer algo" (Willems citado por Bastian, 1983: 84). Los protestantismos rurales se caracterizan por ser religiones "orales", en donde la Biblia es un elemento mágico y protector (siendo una parte que se apega a la cultura y cosmovisión mágico religiosa), que además es parte del discurso mismo, en donde la prédica, que viene a hacer las veces del relato tradicional (mitos y cuentos), en donde la lectura de la Biblia en forma de rito, va aparejada con la práctica de los relatos bíblicos. Los ritos importados por las sectas en las comunidades se caracterizan por la efusividad de manifestaciones comunitarias emocionalismo y excitación en el ritual hacia Dios como danzas y cantos, testimonios, evocaciones milagrosas.

\section{Bibliografía}

Arellano Belloc, Francisco, 1961: "López Mateos, el indio y el Instituto Lingüístico” en A William Cameron Townsend. El XXV aniversario del ILV. México: Tipografía Indigena.

Arellano Sánchez, José, 1989: San Juan Lalana una investigación sociológica sobre la resistencia indígena, México: UNAM-FCPyS Tesis de Maestría. Bastian, Jean Pierre, 1983: Protestantismo y sociedad en México. México: Ed. Casa Unida de Publicaciones. 
Careaga, Gabriel. 1983: "La intolerancia de las sectas" en El Universal 8 Julio, 1983. CONAFE, 1987: Encuesta sobre la penetración de grupos religiosos en comunidades con cursos comunitarios, México: CONAFE

Dávila, Carlos A, 1975: "EL ILV y la penetración ideológica” en La Crónica, Noviembre de 1975, Lima Perú.

Durkheim, Emilio, 1989: Las formas elementales de la vida religiosa, México: Colofón

Elizaga, Julio, 1990 Las sectas y las nuevas religiones, México Ed. Parroquial.

Giménez, Gilberto, 1989: Las sectas religiosas en el sureste, México: Ed. Casa Chata, CIESAS.

Macín, Raúl, 1988: El protestantismo en México, México: Fondo de Cultura Económica.

Mariategui, José, 1979: EIIL Ven México, México: Colegio de Etnólogos y Antropólogos

Maza, Enrique, 1977: El Instituto Lingüistico de Verano, México: Colegio de Etnólogos y Antropólogos.

Ochoa Zazueta, José Ángel, 1975: El Instituto Lingüistico de Verano en México. México: INAH Cuadernos de Trabajo

Pike, K. 1974: Informe de labores, México: ILV.

Pozas, Ricardo, 1976: Antropología y burocracia indigenista, México Ed. Tlacuillo (Cuadernos para trabajadores).

Robertson, Roland, 1980: "Una tipología de las sectas" en Sociología de la religión, México: Fondo de Cultura Económica.

Rodríguez, José, 1990: El poder de las sectas, México: Ed. Zeta.

Santoyo Rodríguez, Margarita, 1992: La penetración del instituto Lingüistico de Verano que fomenta el establecimiento y expansión de las sectas religiosas protestantes en las comunidades indigenas de la Chinantla. San

Juan Lalana, Oax., México: UNAM-FCPyS Tesis de Maestría.

Saldaña, Angel, 1990: Las sectas en México, Oaxaca: Instituto de Investigaciones Sociológicas de la U.A. Benito Juárez..

Warner, Stark, 1986: Las sectas protestantes, México: Fondo de Cultura Económica (Colección popular).

Wilson, Bryan, 1970: Sociología de las sectas religiosas, Madrid: Ed. Guadarrama 